\title{
新型光电功能器件的科学前沿和应用
}

陈志坚

北京大学物理学院, 人工微结构和介观物理国家重点实验室, 北京 100871

E-mail: zjchen@pku.edu.cn

\section{Frontiers in science and applications for new optoelectronic devices}

\section{Zhijian Chen}

State Key Laboratory for Artificial Microstructures and Mesoscopic Physics, Department of Physics, Peking University, Beijing 100871, China E-mail: zjchen@pku.edu.cn

doi: 10.1360/TB-2021-0463

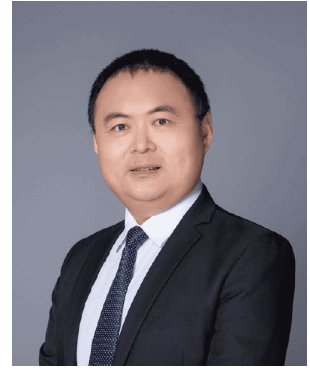

\section{陈志坚}

北京大学物理学院教授, 博士生导 师. 主要研究方向为有机电致发光 和光伏器件结构设计及物理机制 研究.
有机、有机/无机复合光电器件近年来发展迅猛，并且已经逐步走进我们的 生活，在信息显示领域(如可折叠柔性显示屏)和新能源领域(如太阳能电池)应用 广泛. 中国学者在此领域作出了重要贡献. 为了集中展示该领域的发展, 《科学 通报》组织“光电功能材料和器件专题”, 邀请国内专家和学者, 结合自己的研究 工作撰写文章, 对光电材料和器件的发展进行梳理和总结, 并对发展前景进行展 望. 该专题共包含 10 篇文章.

有机电致发光器件(organic light-emitting devices, OLEDs)作为一种新的显示 照明技术，正迅速占据着信息显示的市场. OLEDs的研究可以追溯到 20 世纪 60 年 代 ${ }^{[1]}$. 1987年, Tang和VanSlyke ${ }^{[2]}$ 发明了一种双层薄膜异质结结构的OLEDs, 其器 件外量子效率(internal quantum efficiency，EQE)首次超过 $1 \%$ ，最大亮度达到 $1000 \mathrm{~cd} / \mathrm{m}^{2}$, 为里程碑工作. 自此, 有机光电材料和器件成为研究前沿热点. 在本 专题中, 李福山课题组 ${ }^{[3]}$ 聚焦于可溶液加工纳米光电材料与器件, 介绍了近年来 该领域的研究进展; 肖静课题组 ${ }^{[4]}$ 围绕Richardson-Schottky(RS) 热注入和FowlerNordheim(FN)量子隧穿两种电子注入模型, 讨论了提升倒置有机发光二极管中 电子注入效率的研究进展; 向超宇和钱磊课题组 ${ }^{[5]}$ 从大尺寸OLED显示技术现状 开始，简介了喷、墨打印OLED相关材料与器件的进展及其在大尺寸显示领域的 应用。

随着钙铁矿材料的兴起, 钙钛矿发光二极管也成为研究的热点之一. 吴朝新 课题组 ${ }^{[6]}$ 基于钙钛矿量子点的电致发光器件研究进展, 分析了制约钙钛矿量子点 电致发光二极管效率的主要因素; 肖立新课题组 ${ }^{[7]}$ 从提升钙钛矿发光层发光量子 产率与调整器件结构提升电荷平衡因子和光耦合因子两方面, 总结了目前钙钛 矿发光二极管中提升器件外量子效率的策略.

为了解决目前OLEDs中镉、铅等元素的危害性问题, 多元铜基硫族半导体 纳米晶受到了广泛关注. 唐爱伟和滕枫课题组 ${ }^{[8]}$ 介绍了多元铜基硫族半导体纳 米晶的组分、表面配体、晶体结构和纳米结构等因素对其发光特性的影响, 着 重阐述了多元铜基硫族半导体纳米晶在电致发光器件中的研究进展. 
随着人类对清洁可再生能源的需求持续增加, 太阳能电池有望成为未来能源的主要来源. 钙钛矿太阳能电池 (perovskite solar cells, PSCs) 自2009年被报道以来, 仅仅10余年就达到了 $25.5 \%$ 的认证效率, 远远超过以往任何一种 太阳能电池的发展速度, 迅速成为新能源研究领域的宠儿 ${ }^{[9]}$. 在本专题中, 王吉政课题组 ${ }^{[10]}$ 总结了钙钛矿晶体中各 类缺陷的形成过程与物理性质, 并分析了各类缺陷对太阳能电池工作的影响; 同时, 从界面钝化层出发, 介绍了多 种材料作为界面钝化层的钝化机制与钝化效果, 通过对现有研究成果的分析, 总结出有效的界面钝化思路与策略.

在非铅钙钛矿研究领域, 孟庆波课题组 ${ }^{[11]}$ 对CZTS(e) 太阳能电池高开路电压损耗的根源、CZTS(e):Ge太阳能 电池的制备方法以及Ge对CZTS(e) 太阳能电池器件性能的影响进行了重点介绍, 并对CZTS(e):Ge太阳能电池的未 来研究方向进行了展望; 刘志伟课题组 ${ }^{[12]}$ 结合锡基钙钛矿的结构和性质, 分别从添加剂和组分调控两个角度综述 了锡基钙钛矿太阳能电池近年来的重要研究进展.

基于有机和有机/无机杂化材料的光电器件有望成为下一代重要半导体器件, 具有极大商业前景. 相信该专题 文章会对读者有所帮助. 在此, 衷心感谢各位供稿专家, 感谢《科学通报》编辑部对本专题出版的支持与帮助!

\section{参考文献}

1 Pope M, Kallmann H P, Magnante P. Electroluminescence in organic crystals. J Chem Phys, 1963, 38: 2042-2043

2 Tang C W, VanSlyke S A. Organic electroluminescent diodes. Appl Phys Lett, 1987, 51: 913-915

3 Liu Y, Zhu Y B, Ma F M, et al. Solution-processable nano-optoelectronic materials and devices (in Chinese). Chin Sci Bull, 2021, 66: 2095-2104 [刘洋, 朱阳斌, 马福民, 等. 可溶液加工纳米光电材料与器件. 科学通报, 2021, 66: 2095-2104]

4 Jiang H H, Xiao J, Yin Z Y, et al. Progress and outlook on electron injection in inverted organic light-emitting diodes (in Chinese). Chin Sci Bull, 2021，66: 2105-2116 [姜慧慧, 肖静, 殷照洋, 等. 倒置有机发光二极管中电子注人的研究及发展. 科学通报, 2021, 66: 2105-2116]

5 Tang Z B, Ding S, Kang K, et al. Application of inkjet printing in the large area display of organic light-emitting diode (in Chinese). Chin Sci Bull, 2021, 66: 2117-2128 [唐兆兵, 丁硕, 康凯, 等. 喷墨打印在大尺寸OLED显示中的应用. 科学通报, 2021, 66: 2117-2128]

6 Zhao C J, Yu Y, Dai J F, et al. Advances on perovskite quantum dot electroluminescent devices (in Chinese). Chin Sci Bull, 2021, 66: 2139-2150 [赵晨静, 于跃, 代锦飞, 等. 基于钲钛矿量子点的电致发光二极管研究进展. 科学通报, 2021, 66: 2139-2150]

7 Yu W J, Zhang Y Q, Qu B, et al. Strategies to improve the external quantum efficiency of perovskite light emitting diode (in Chinese). Chin Sci Bull, 2021, 66: 2151-2161 [俞文锦, 张雨晴, 曲波, 等. 钙钛矿发光二极管外量子效率提升策略. 科学通报, 2021, 66: 2151-2161]

8 Zhang J, Wang L J, Chen F, et al. Optical properties of multinary copper chalcogenide semiconductor nanocrystals and their applications in electroluminescent devices (in Chinese). Chin Sci Bull, 2021, 66: 2162-2178 [张京, 王立瑾, 陈斐, 等. 多元铜基硫族半导体纳米晶的发光性能 及其在电致发光器件中的应用进展. 科学通报, 2021, 66: 2162-2178]

9 Kojima A, Teshima K, Shirai Y, et al. Organometal halide perovskites as visible-light sensitizers for photovoltaic cells. J Am Chem Soc, 2009, 131: $6050-6051$

10 Niu G S, Zhuang J, Luan Y G, et al. Progress on defects and interfacial passivation layers in hybrid perovskite solar cells (in Chinese). Chin Sci Bull, 2021, 66: 2179-2201 [牛国盛, 庄晶, 奕乙刚, 等. 杂化钲钛矿太阳能电池中缺陷与界面针化层的研究进展. 科学通报, 2021, 66: 21792201]

11 Xu X, Zhou J Z, Guo L B, et al. Overview of Ge-incorporated kesterite solar cells (in Chinese). Chin Sci Bull, 2021, 66: 2202-2214 [徐啸, 周家正, 郭林宝, 等. 锗掺杂/替位锌黄锡矿太阳能电池研究进展. 科学通报, 2021, 66: 2202-2214]

12 Wang C B, Gu F D, Bian Z Q, et al. Advances on tin-based perovskite solar cells (in Chinese). Chin Sci Bull, 2021, 66: 2129-2138 [王程博, 顾飞 丹, 市祖强, 等. 锡基钻钛矿太阳能电池研究进展. 科学通报, 2021, 66: 2129-2138] 